\title{
PEDIATRICS
}

UDC 616.379-008.64

\section{Nutritional stereotypes of children with insulin-dependent diabetes mellitus}

\author{
A. N.Zavyalova, O. V.Lisovskii, V.P. Novikova, \\ M. N. Yakovleva, A. V. Gostimskii, L. V. Tyrtova, I. A. Lisitsa
}

St. Petersburg State Pediatric Medical University,

2, Litovskaya ul., St. Petersburg, 194100, Russian Federation

For citation: Zavyalova A.N., Lisovskii O. V., Novikova V.P., Yakovleva M.N., Gostimskii A. V., Tyrtova L. V., Lisitsa I.A. Nutritional stereotypes of children with insulin-dependent diabetes mellitus. Vestnik of Saint Petersburg University. Medicine, 2021, vol. 16, issue 1, pp. 3-12.

https://doi.org/10.21638/spbu11.2021.101

In most cases, type 1 diabetes mellitus is an autoimmune disease characterized by the destruction of insulin-producing beta cells, which is the result of absolute insulin deficiency and, therefore, treatment is associated with the administration of insulin. The therapeutic treatment of type 1 diabetes includes the use of insulin for glycemic control, balanced nutrition and regular physical activity. Daily insulin requirements vary depending on age, diet, self-monitoring of blood glucose and daily routine. Obesity affects some patients with type 1 diabetes, which increases their insulin requirements and negatively affects their metabolic control. The type 1 diabetes diet is an essential part of the treatment program and helps to achieve glycemia targets and avoid insulin dose difficulties. Traditionally, for sick children and their parents, there are diet classes in the School of diabetes, but the equivalence in terms of diet and the actual nutrition of children is not sufficiently studied. Therefore, a combination of insulin therapy and an individual nutrition plan is necessary, which is the key to proper metabolic control. The usual nutritional guidelines for patients with type 1 diabetes should be the same as those for the general population.

Keywords: School of diabetes, diabetes mellitus, insulin, bread units, nutrition, glycemia, physical growth, metabolic control, body mass index.

\section{Introduction}

Diabetes mellitus (DM) in children is one of the main health problems due to high prevalence, constant increase of morbidity, development of serious complications leading to disability and risk of death. Over the past 10 years, there has been an increase in DM

(C) St. Petersburg State University, 2021 
incidence worldwide. According to statistics, between $1 \%$ and $3 \%$ of the world's population suffers from SD. This represents between 50 and 150 million people. In Russia, at least $3.06 \%$ of the population is infected with this disease. Of these, $6-8 \%$ of children under the age of 14. Current trends in child morbidity include an annual increase in the number of cases of insulin-dependent DM to $6 \%$ and a rejuvenation of the age of the type 1 diabetes mellitus demonstration [1-4].

Despite the classes held at the School of diabetes for patients with the first identified $\mathrm{DM}$, the role of nutrition in the therapy of this disease is poorly evaluated by parents. In Russia, it is traditional to recommend diets no. 9 by M.I.Pevzner as physiologically reasonable for this category of patients. Taking meals 5-6 times a day in small portions strictly according to the regime allows to prevent critical changes in blood of glucose concentration. The caloric value of the food, the ratio of proteins, fats and carbohydrates in the diet should be in accordance with the principles of healthy nutrition, and should not exceed the amount of carbohydrates recommended for the age and mass of the child, expressed in bread units (BU). Nutrition planning is an essential component of compensation of DM. The diet, daily energy value of the diet, and the amount of BU when selecting initial insulin therapy should be standardized and rational. This will help to achieve more effective target parameters of glycemia and to prevent of difficulties in the dosing of insulin $[4 ; 5]$.

There are few studies of food stereotyping and compliance with DM diets in the world. This is facilitated by the information from untrusted sites that there is no need to observe a diet with $\mathrm{BU}$ counting and the restriction of easily digestible carbohydrates if the patient is on insulin therapy; it is necessary simply to keep a healthy diet [6].

The purpose of the work is to study the nutritional status and stereotyping of children with insulin-dependent DM through patient questionnaires and physical development assessments.

\section{Materials and methods of research}

A single-centre study was carried out in the endocrinological department of the multi-disciplinary children's hospital. The unit has 45 beds available 24 hours a day. About $70 \%$ of patients with DM are treated annually. The study includes 56 couples (parent / child) with an insulin-dependent DM receiving routine specialist care. A survey of all patients was conducted. The physical development of children was evaluated using the WHO Central Tables. All parents gave their informed consent before taking part in the scientific work. The study was conducted in accordance with the Helsinki Declaration. Statistical processing of the results was carried out using Microsoft Excel 2016 and Statistica 12 software.

\section{Results}

Children entering the endocrinological department have been screened. Children aged 3-18 years, average 7.5 years; 23 (41\%) boys and 33 (59\%) girls. Thirty-nine children $(69.7 \%)$ have no DM family history; 17 (30.3\%) have type 2 diabetes with grandparents. Depending on the duration of the disease, children were divided into 6 groups: up to 1 year, 5 (8.9\%) children; $1-3$ years, 12 (21.4\%) children; $3-5$ years, $16(28.5 \%)$; 


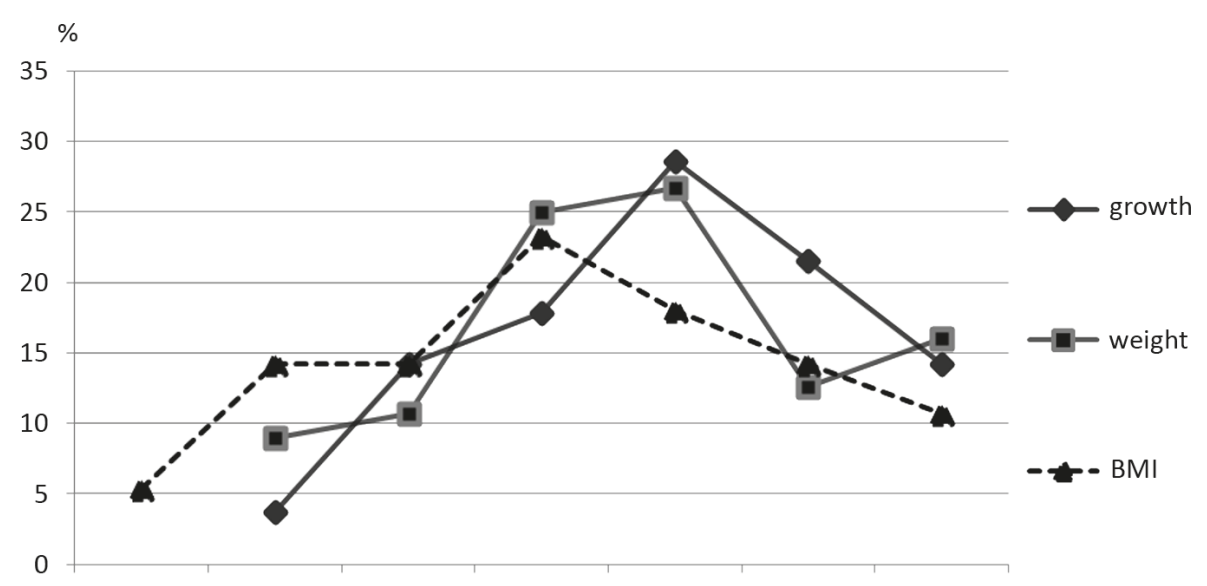

Fig. 1. Physical development of children

5-8 (26.7\%) patients; 8-10 (7.1\%) children; and 10-15 (7.1\%) children. Insulin was injected in basic bolus mode to 41 patients $(73.3 \%)$; insulin therapy by insulin pump was administered to $15(26.7 \%)$ patients.

Complications of diabetes mellitus in the study group. Diabetic retinopathy was detected in $12(21.4 \%)$ children, liver steatosis in $3(5.3 \%)$ children, postinjective lipodistrophy was reported in $3(5.3 \%)$ cases; diabetic nephropathy was diagnosed in 2 (3.5\%) patients, diabetic neuropathy in the lower extremities occurred in 2 cases (3.5\%). Fifteen patients $(26.7 \%)$ were diagnosed with allergies, and four $(7.1 \%)$ were diagnosed with nutritional intolerance.

Physical development is estimated using centile growth corridors [7] (fig. 1). Growth: 2 corridors (low area) -2 (3.6\%) children; 3 corridors (below average) $-8(14.2 \%)$; 4 corridors $-10(17.8 \%) ; 5$ corridors (above average) $-16(28.5 \%)$ patients; 6 corridors (high area) $-12(21.4 \%)$ patients; 7 corridors and above (very high area) $-8(14.2 \%)$ cases.

Body mass: 2 corridors (low area) $-5(8.9 \%)$ of patients; 3 corridors (below-average area) $-6(10.7 \%)$ of children; 4 corridors (medium area) $-14(25 \%)$ of cases, 5 corridors (above-average area) -15 (26.7\%) of observations; 6 corridors (high area) -7 (12.5\%) patients; 7 corridor and higher (very high area) -9 children (16.0\% of patients).

Body mass index (BMI): 1 corridor (very low area) $-3(5.3 \%)$ of the child; 2 corridor (low area) $-8(14.2 \%)$ of cases; 3 corridor (below average area) $-8(14.2 \%)$ of patients; 4 corridor (medium area) - $13(23.2 \%)$ of observations; 5 corridor (above average) $-10(17.8 \%)$ of patients; 6 corridor (high area) $-8(14.2 \%)$ of patients; 7 corridor and above $-6(10.7 \%)$ of children.

Thus, the physical development and nutritional status of children with DM is not distinctly different from those of healthy children, and reflects the worldwide trends of increasing BMI in the population of children [6-8]. However, attention is drawn to a small group of underweight and stunted children. Furthermore, when asked about the child's body mass, either by the parents or by the child himself, 13 (23.3\%) persons noted a lack of body mass, and $5(8.8 \%)$ respondents indicated an excess body mass. Reliable correlations have been found between the centile growth and body mass corridors and the length of diabetes. The longer the duration of diabetes, the higher the centile growth corridor 
$(0.208376, \mathrm{p} \leq 0,05)$ and body mass $(0.215782, \mathrm{p} \leq 0,05)$, which is explained by the anabolic effect of insulin hormone $[5 ; 6 ; 9]$.

The nutritional behaviour of children often reflects the parents' view of the need to maintain a diet. In the family, the child eats what the parents offer him or her. School of diabetes, as a rule, gives the concept of the correct and healthy nutrition, but can be found a lot of reasons for the violation of the diet, from the non-acceptance of dietary therapy to the insufficient financial well-being of the family, and the choice of the cheapest "food basket" [10].

In our study, 13 (23.5\%) children frequently violated their diet, $20(35.7 \%)$ were sometimes disturbed, $15(26.7 \%)$ violated their diet "rarely" and only $9(16 \%)$ did not violate their diet at all. The frequency of consumption of different groups of products has been studied: cereals - porridge and pasta; vegetables and fruits; meat of different animals; fish; milk and dairy products; eggs. Parents noted the frequency and size of the portion of the child they consumed. The appetite was better for boys. They preferred poultry meat, vegetables and fruit. The girls preferred cereals, fruit, dairy products.

Eating habits and daily intake of foodstuffs.

1. Cereals. Sources of easily digestible carbohydrates: 7 (12.5\%) of children's porridge, $10(17.8 \%)$ of patients' corn porridge, $20(35.7 \%)$ of respondents. In general, the parents offered "regular" cereals. Oatmeal was the most popular in $44(78.5 \%)$ patients and in $49(87.5 \%)$ brown cereals. Wheat porridge was eaten by 32 patients $(57.1 \%)$, wheat $15(26.7 \%)$, pen $13(23.2 \%)$ and barley 7 (12.5\%).

Eight $(14.2 \%)$ children consumed multi-grain porridge. Most of the children ate milk porridge $-40(71.4 \%)$ observations, and $33(58.9 \%)$ had butter. Twenty-four $(42.8 \%)$ of the children had porridge that was scattered, dense; two (3.5\%) had cereal for breakfast. Cereal cereals with "fast" carbohydrates consumed a third of the children in the sample, which was an indirect violation of the specialized diet. Breakfast is the food that is most often eaten at home, and therefore it is possible to assess the family influence on eating behaviour and the formation of nutritional stereotypes to maintain the target blood glucose level after eating [11].

Pasta products, especially from traditional soft wheat varieties in our country, are frequent in the diet of children with DM, which is a direct violation of the special diet. Thus, 29 (51.7\%) children ate pasta $2-3$ times a week and 15 (26.7\%) a day. Six people (10.7\%), five people $(8.9 \%)$ were not eaten once a week, and two people ( $2 \%)$ were not eaten at least once a week. Most of the time, macaroni was eaten with cheese 32 (58.0\%); meat was eaten by $28(50.0 \%)$ children and ketchup was eaten by $14(26.0 \%)$. Traditionally, black bread has been allowed from bakeries for diabetes mellitus patients, and it has been in the daily diet of 54 (96.4\%) children. Prohibited white bread was consumed by 23 (41\%) people every day in the form of sandwiches or simply batons.

2. Twinned products, sources of easily digestible carbohydrates. In the diet of two children (3.6\%) were steering-wheels; $2(3.6 \%)$ were bagels; 5 (8.9\%) were gingerbread; 7 (12.5\%) were cake, 13 (23.2\%) were crackers; 16 (28.5\%) were waffles; $17(30.3 \%)$ were sweet drying; 21 (37.5\%) were biscuits; 40 (71.4\%) were ice cream and 1 (1.1\%) were pies. The use of easily digestible carbohydrates, especially in the form of confectionary products, increases postprandial glycemia and leads to earlier development of complications. Sandwiches are in the diet of $46(82.1 \%)$ children, which may not always be considered as a violation of the diet if the bread is picked with rye or multi-grain (Fig. 2). 


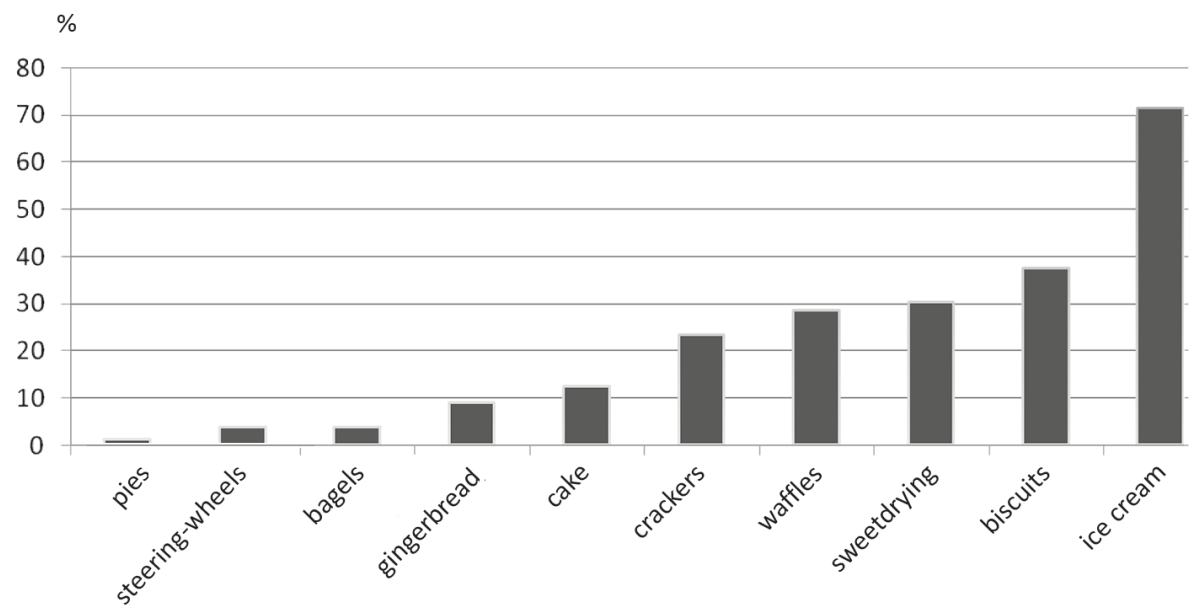

Fig. 2. Frequency of consumption of bakery and confectionery products in the diet of children with DM

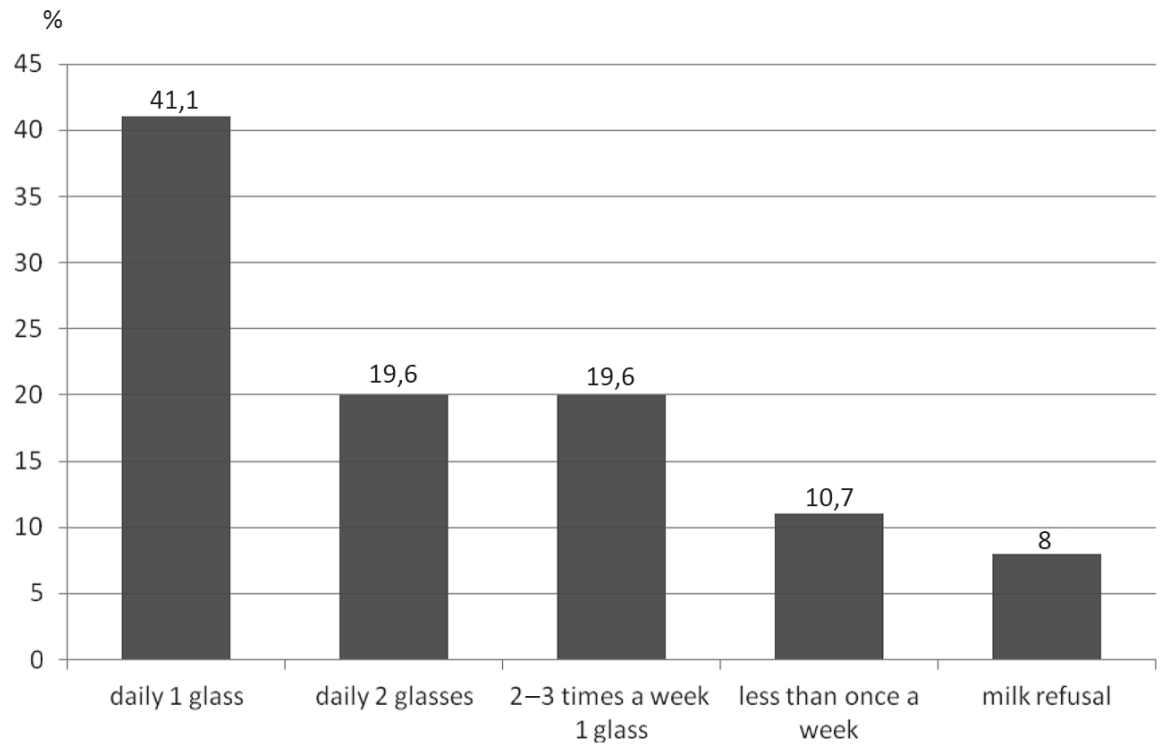

Fig. 3. Frequency of milk and sour milk consumption

3. Milk and kefir were consumed daily by 23 children (41.1\%), of whom 11 (19.6\%) drank two glasses, which is the physiological norm for children [12]. The same number of children $11(19.6 \%)$ drank dairy products $2-3$ times a week and $6(10.7 \%)$ consumed less than once a week. Four ( $8 \%$ ) of the population (Fig. 3) abandoned dairy products. Raw cottage cheese made by 35 (62.5\%) children, cheese by $19(33.9 \%)$ patients, casserole by $14(25.0 \%)$ patients, cottage cheese with fruit by $2(3.5 \%)$ children with DM. The consumption of cheesecake can be considered a complete violation of the diet, which is noted in $7(12.5 \%)$ observations. In the daily diet, 8 (14.2\%) patients had cottage cheese or curd, 2-3 times a week in 25 (44.7\%) cases. Twelve (21.4\%) children did not consume cottage cheese. 
Twenty-eight (50.0\%) of those surveyed had cheese in their daily diet, $16(28.6 \%)$ of the children consumed it 2-3 times a week, $6(10.7 \%)$ of the patients consumed it less than once a week and $6(10.7 \%)$ did not eat any cheese. Sour cream $16(28.6 \%)$ ate daily, $21(37.6 \%)$ ate $2-3$ times a week, $10(17.8 \%)$ ate sour cream less than once a week, and $9(16.0 \%)$ declined it in their diet.

Eggs, as the source of a fully digestible protein, must be 1 per day in a child's daily diet. Only 11 (19.7\%) ate eggs every day, 28 (50.0\%) ate eggs $2-3$ times a week, $12(21.4 \%)$ patients ate eggs less than once a week and $5(8.9 \%)$ did not eat eggs.

Animal proteins (meat) must be present in diet of children. The presence of 26 (46.4\%) children in the dumplings diet indirectly indicated a deficiency in diet. The dough for this dish is traditionally made of wheat flour. Every day, 34 (60.8\%) respondents have meat on the menu, $20(35.8 \%)$ patients have it 2-3 times a week, and $2(3.4 \%)$ children have it at least once a week.

Fish, as a source of easily digestible protein and essential fats, was in the diet of $17(30.3 \%)$ patients $2-3$ times a week, in $6(10.8 \%)$ children daily. Did not eat fish $14(25.0 \%)$ of the respondents. The fish was cooked in a variety of ways.

For the growing body of a child, the fat component is very important. Most of the $35(62.5 \%)$ children had butter in their diet, $3(5.3 \%)$ had light oils and $1(1.7 \%)$ had margarine. Vegetable oil as a source of polyunsaturated fatty acids is the sum of all the children on the menu.

The potatoes, depending on the cooking, contain different amounts of BU. Half of the respondents, 31 (55.4\%), ate potato dishes 2-3 times a week, 20 (35.7\%) daily, and $4(7.2 \%)$ patients less than once a week. Mashed potatoes were on the menu for $46(82.1 \%)$ patients, boiled potatoes for $38(67.8 \%)$ cases, baked potatoes for $23(41.0 \%)$ children, roasted potatoes for $18(32.1 \%)$ patients, boiled potatoes with butter for $21(37.5 \%)$ observations.

Vegetables are the main suppliers of carbohydrates, vitamins, mineral salts and fibres needed for the normal functioning of the organism. Forty-nine $(87.5 \%)$ of the respondents consumed vegetables daily, usually in the form of salads. The remaining vegetables are not eaten. Among of fresh vegetables, 54 (96.4\%) and 48 (85.8\%) of respondents were eating cucumbers. Fresh carrots were eaten by 40 (71.5\%) children, green by $21(37.5 \%)$, fresh peppers by $18(32.2 \%)$, white cabbage by $10(17.9 \%)$ and beet by $1(1.8 \%)$. Among thermally treated vegetables, cabbage stew predominated in $44(78.6 \%)$ patients, beetroot $24(42.9 \%)$, carrot $30(53.6 \%)$, courgette $25(44.7 \%)$ and pumpkin $6(10.8 \%)$ respondents.

Fruit. Children ate $47(84.0 \%)$ per day and $8(14.3 \%)$ per week. The patients most often preferred apples, pears, and oranges. Rarer ate kiwi, peaches, plums, apricots and mangoes. Bananas not allowed under DM were eaten by 25 (44.7\%) children, grapes by $1(1.7 \%)$ child.

Fruit juices were in the daily diet of $6(10.8 \%)$ patients, $2-3$ times a week of $7(12.5 \%)$ children, less than 1 time a week of 26 (46.5\%). In other observations, the children did not drink juice. Of those who drank juice, 35 (62.5\%) had one cup of juice, while the remaining $4(37.5 \%)$ had two to three glasses of juice. It should be noted that it is easily digested carbohydrate, which dramatically increases blood glucose levels (Fig. 4).

The majority of DM patients reported that $47(84 \%)$ children did not consume sugar. $2-3$ teaspoons of tea were consumed daily by $9(16.0 \%)$ patients, which is a gross violation of the diet. Chocolate were in the diet of $23(41.0 \%)$ children, and sweets was used 


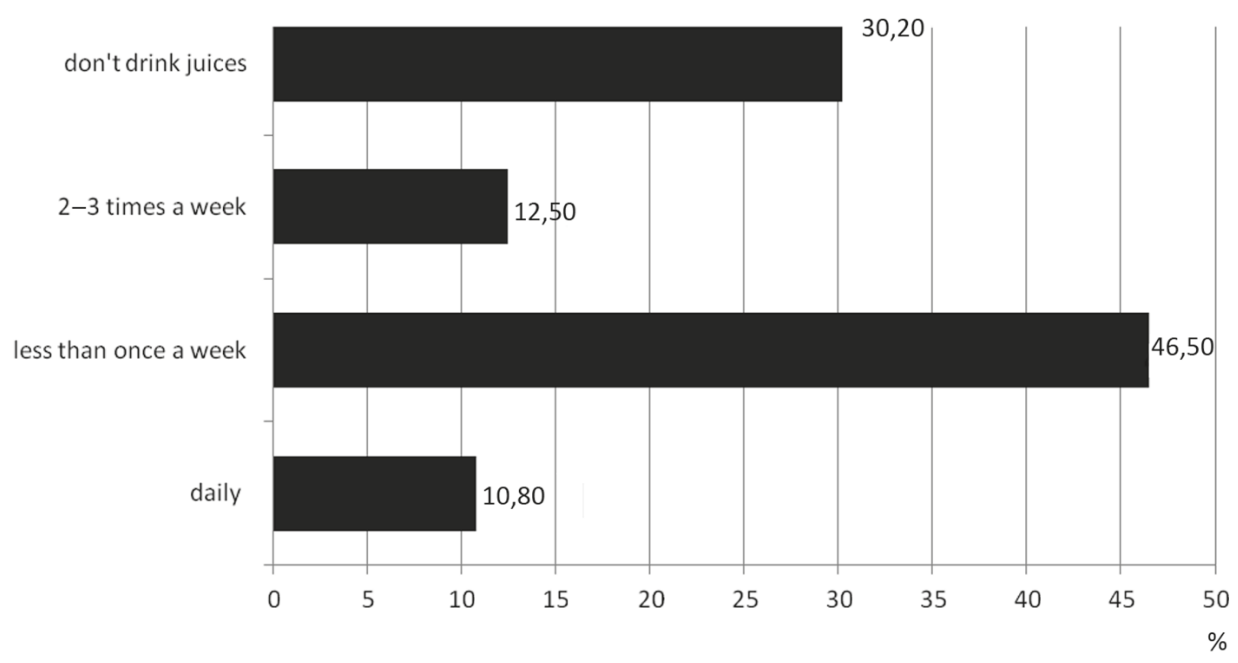

Fig. 4. Frequency of juice consumption

by $16(28.5 \%)$ patients. A gums was used by $26(46.4 \%)$ respondents. Traditional sweets should not be eaten by children with DM. They cause postprandial hyperglycemia. The only sweetness allowed in the diet, based on stevia.

Fast food, snacks and carbonated beverages. Even healthy children can't eat fast food. However, current trends, advertising and collective behaviour in school and adolescence communities dictate certain behaviours. Sweet carbonated beverages drank 22 (39.3\%) of the respondents, the choice being sprite, pepsi and other sweet lemonades, with 13 (22.3\%) children in their daily diet. Crisps 2-3 times a week in the diet of $3(5.3 \%)$ patients with $\mathrm{DM}$, crackers $2(3.5 \%)$, potato-fries $4(7.1 \%)$ patients. However, about $65 \%$ of children are reasonably spared snow products and fast food enterprises. This may be due to the frequent associated type of DM 1 chronic gastroduodenitis [13-17].

According to the survey, not all families were mode of diet. Most children had breakfast in the morning for 55 (98.3\%). At school, 27 (48.3\%) of schoolchildren ate lunch, usually a full three-course meal (soup, second and drink). In 21 children (37.5\%), the lunch consisted only of soup and drink, in 9 children (16\%) it consisted of a second course and a drink. Unfortunately, 7 (12.5\%) had lunch with sandwiches. Home dinner is usually with meat in $48(85.7 \%)$ children, and dinner in $3(5.3 \%)$ is more often than a fish dish with garnishes. Again, 14 (25.0\%) children are occasionally eaten for dinner with sandwiches.

The questionnaire specified the mother's educational level: $48.3 \%$ with higher education, $8.9 \%$ with incomplete higher education, $33.9 \%$ with secondary vocational education and $8.9 \%$ with secondary education. Fathers' education: $44.7 \%$ - higher education, $8.9 \%$ - incomplete higher education, $35.8 \%$ - secondary vocational education, $1.7 \%$ general secondary education (Fig. 5).

Unfortunately, $8.9 \%$ of children have fathers who are not involved in child-rearing. $64.4 \%$ of mothers are working, 1 mother $(1.7 \%)$ is studying and $34 \%$ are housewives. In full families, $96 \%$ of fathers work and 2 children (4\%) have a pensioner's father.

There was a strong direct correlation between the mother's education and the child's eating disorders. In families of highly educated mothers, there is no deviation from the 


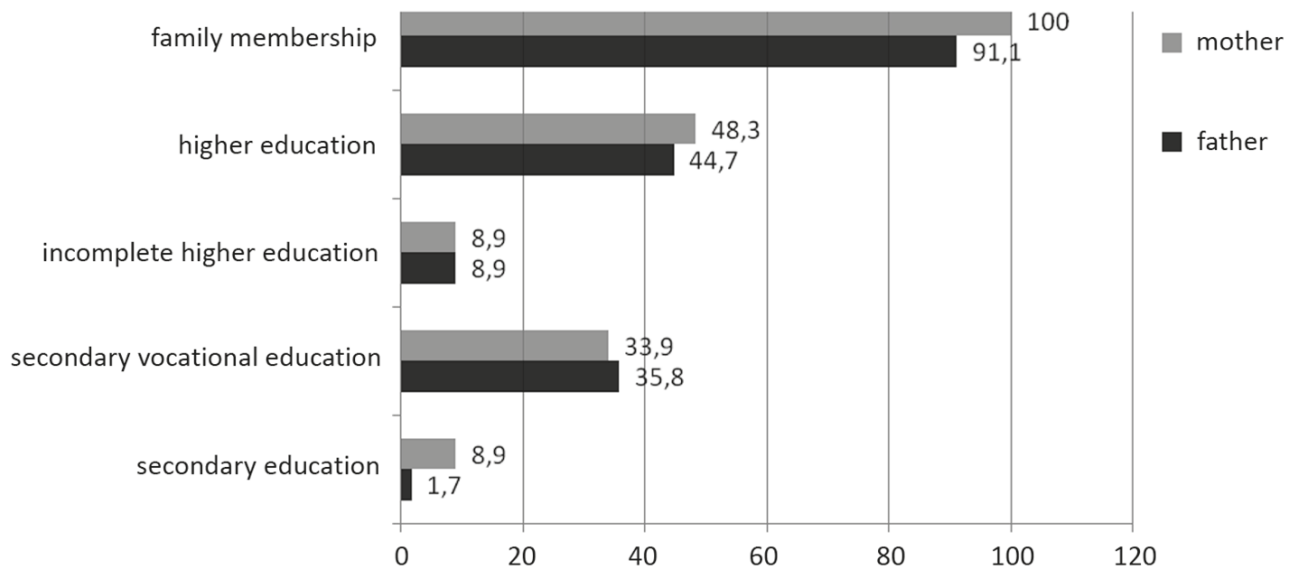

Fig. 5. Educational level of parents

$\operatorname{diet}(0.224013345 \mathrm{p} \leq 0,05)$, while the lower the education of the father, the less the violation of the diet $(0.20316718 \mathrm{p} \leq 0,05)$. The findings highlight the role of social factors in supporting compassion in paediatric practice [20].

Conclusion. The non-compensated DM is known to cause poor health, so the child's well-being was relevant. Forty-seven (80.4\%) of the children reported well, seven (12.5\%) said that they were satisfied and only four (7\%) said that they were not well. During the last school year, $6(10.7 \%)$ children suffered a deterioration in their well-being, $35(62.5 \%)$ and $15(26.8 \%)$ respondents improved.

Clinical symptomatology of partial insufficiency of vitamins and minerals has been detected [19]. In $6(10.7 \%)$ cases without complaints, the others described various symptoms. $28(56.0 \%)$ children were irritated; $19(38.0 \%)$ patients were fatigued; $16(32.0 \%)$ respondents were fatigued intermittently; $14(28.0 \%)$ patients were sluggish, depressed and drowsy during the day; $9(18.0 \%)$ were restless, 8 (16.0\%) They experienced difficulty in falling asleep, learning difficulties and frequent cold diseases. Twenty-two (44.0\%) patients had their skin dried, and $1(2.0 \%)$ had their skin thinned and their hands were hyperemic. Three $(6.0 \%)$ of the children complained about their toenails being slim, and two $(4.0 \%)$ complained about their hair being dry.

Pain in the legs disturbed 17 (34.0\%) children, muscle weakness $6(12.0 \%)$ children, occasional headaches $15(30.0 \%)$ patients, visual impairment $13(26.0 \%)$ and $12(24.0 \%)$ respondents - memory impairment and poor healing. Haemorrhaging of the gums was found in $5(10.0 \%)$ patients, ecthimosis and oral fractures in 7 (14.0\%). Periodic heart pains in 4 (8.0\%) of children, in 3 (6\%) hyper-heartbeat, tingling in the chest. Poor appetite and unstable chair in $3(6 \%)$ respondents. Enriched foods were in the diet of all children. Only 21 respondents $(37.5 \%)$ received vitamin-mineral subsidies.

Thus, the physical development of children with DM is not distinctly different from that of healthy children, and reflects worldwide trends towards increasing BMI in the child population. The duration of diabetes is associated with increased weight and height due to the anabolic effects of insulin hormone. The nutritional status of children in DM1 is characterized by mineral and vitamin deficiencies. Only $18 \%$ of children have a diet. It is higher in families with a mother's higher education and the father's secon- 
dary education. These results will be useful for the work of nutritionists in School of diabetes.

\section{References}

1. Dedov I. I., Shestakova M. V., Vikulova O.K., Zheleznjakova A. V., Isakov M. Diabetes mellitus in the Russian Federation: prevalence, morbidity, mortality, parameters of carbohydrate exchange and structure of sugar-bearing therapy according to the Federal Register of Diabetes Mellitus, Status 2017. Saharnyj diabet, 2018, no. 21 (3), pp. 144-159. (In Russian)

2. Federal State Statistics Service. Available at: http://www.gks.ru (accessed: 12.04.2020). (In Russian)

3. Algorithms for specialized care of diabetics, eds I. I. Dedov, M. V. Shestakova. Moscow, 2015. Vyp. 7. 120 p. (In Russian)

4. Nikitina I. L., Skorodok Ju. L., Ditkovskaja L. V., Novikova V.P., Grineva E. N. Diabetes mellitus in children and adolescents. Moscow, 2016. (In Russian)

5. Federal Clinical Guidelines for Diagnosis and Treatment of Type 1 Diabetes Mellitus in Children and Adolescents. 09.2013. S. 8. (In Russian)

6. American Diabetes Association. Standards of Care in Diabetes Mellitus. 2017, transl. by Ivanov D. D., Ivanova M. Pochki, 2017, vol. 6, no. 1, pp. 47-63. (In Russian)

7. Simahodskij A.S., Novikova V.P., Kagan A.V., Leonova I. A., Gurkina E. Ju., Semenova E. V., Avtomonova T. S., Zorina S. A., Kedrinskaja A. G., Pen’kov D. G., Petrova N. V. Methodology for assessing the child's physical development. St. Petersburg, 2018. (In Russian)

8. Gricinskaja V.L., Novikova V.P. Trends in regional physical development indicators for schoolchildren in Saint Petersburg, Profilakticheskaja i klinicheskaja medicina, 2019, no. 1 (70), pp. 17-21. (In Russian)

9. Hudorozhkova O.M., Smirnova E. N. Assessment of Type 1 Diabetes Relief for Children and Adolescents in the Perm Region. Permskii medicinskii zhurnal, 2019, vol. 36, no. 6, pp. 57-63. (In Russian)

10. Rafiq K., Saify Z.S., Raza A., Hassan A., Rizvi A. The Management of Pediatric Type-1 Diabetes. A Case Study. Bangladesh Journal of Medical Science, 2020, vol. 19, no. 2, pp. 326-332.

11. Anastasiou C.A., Fappa E., Zachari K., Mavrogianni C., Van Stappen V., Kivelä J., Virtanen E., González-Gil E. M., Flores-Barrantes P., Nánási A., Semánová C., Dimova R., Usheva N., Iotova V., Cardon G., Manios Ya., Makrilakis K. Feel4Diabetes-study group. Development and reliability of questionnaires for the assessment of diet and physical activity behaviors in a multi-country sample in Europe the Feel Diabetes Study. BMC Endocrine disorders, 2020, vol. 20, no. 135. https://doi.org/10.1186/ s12902-019-0469-x

12. Nikitina I. L., Novikova V.P., Aleshina E. I., Gricinskaja V.L., Komissarova M. Ju., Voroncova L. V., Zavyalova A. N. Adolescent nutrition. St. Petersburg, 2017. (In Russian)

13. Detkov V. Ju., Il'inec I. V., Mironjuk E. O., Dosovickaja E. R., Berleva O. V., Fadeeva D. V., Pohlebkina A.A. Endoscopic pattern of mucosa of the upper parts of the digestive organs in adolescents with type I diabetes. Sovremennye problemy podrostkovoi meditsiny i reproduktivnogo zdorov'ia, molodezhi Sbornik trudov Vserossiiskoi nauchno-prakticheskoi konferentsii. St. Petersburg, 2017, pp. 388-389. (In Russian)

14. Mel'nikova I. Ju., Novikova V.P., Tolkacheva N. F., Dmitrieva E. G. Clinical endoscopy of upper digestive tract in children with diabetes mellitus. Sbornik nauchnykh statei $k$ 135-letiiu Detskoi gorodskoi bol'nitsy no. 19 im. K. A. Rauhfusa. St. Petersburg, 2004, pp. 87-93. (In Russian)

15. Pohlebkina A. A., Tyrtova L. V., Novikova V.P. Screening for Celiac in Type 1 Diabetes Mellitus, Materialy XXVI Mezhdunarodnogo Kongressa detskikh gastroienterologov Rossii i stran SNG "Aktualnye problemy abdominal'noi patologii u detei". Moscow, 2019, pp. 170-172. (In Russian)

16. Strukov E. L., Pohlebkina A. A. Etiopatogenetic characteristics of chronic gastritis in type 1 diabetes in adolescents, Sbornik trudov III Nauchno-prakticheskoi konferentsii s mezhdunarodnym uchastiem "Sovremennye problemy podrostkovoi meditsiny i reproduktivnogo zdorov'ia molodezhi. Krotinskie chteniia”. St. Petersburg, 2019, pp. 259-265. (In Russian)

17. Pohlebkina A. A. Stomach condition of children with type 1 diabetes. Sovremennye problemy podrostkovoi meditsiny i reproduktivnogo zdorov'ia molodezhi Sbornik trudov Vserossiiskoi nauchno-prakticheskoi konferentsii. St. Petersburg, 2017, pp. 252-260. (In Russian)

18. Sokolova N. V., Solodkina A. A., Lagno O. V., Kovalev E. A., Aleksandrovich V. Ju. Prevalence of allergpathology and metabolism in children with gastrointestinal diseases, Allergicheskie i immunopatologicheskie zabolevaniia - problema XXI veka. St. Petersburg, 2016, pp. 35-37. (In Russian) 
19. Bel'mer S. V., Havkin A.I., Novikova V.P., Balakireva E. E., Grechanyj S. V., Gurova M. M., Komarova O. N., Komissarova M. Ju., Kochergina T. A., Koshhavcev A. G., Nikolaeva N. O., Sedov V.M., Tokarevich K.K., Troickaja L. A., Tjurin A.G., Horoshinina L. P., Shherbakova M. Ju. Eating behaviour and food programming in children. St. Peterburg, 2015. (In Russian)

20. Orel V. I., Kim A. V., Sereda V.M., Bezhenar S. I., Roslova Z.A., Rubezhov A. L., Buldakova T. I., Rukavishnikov A. S., Libova E. B., Sharafutdinova L. L., Gur'eva N. A. Organization of medical and social work among children. Pediatr, 2018, vol. 9, no. 1, pp. 54-60. (In Russian)

Received: February 15, 2021

Accepted: March 25, 2021

Authors' information:

Anna N.Zavyalova - PhD in Medicine, Associate Professor; anzajalova@mail.ru Oleg V. Lisovskii — PhD in Medicine, Associate Professor; oleg.lisovsky@rambler.ru Valeriya P. Novikova - Dr. Sci. in Medicine, Professor; novikova-vp@mail.ru Milena N. Yakovleva - Dr. Sci. in Medicine; milena-yakovleva@bk.ru AlexandrV. Gostimskii - Dr. Sci. in Medicine, Professor; gostimsky@mail.ru Ludmila V.Tyrtova - Dr. Sci. in Medicine, Professor; dr-tyrtova@yandex.ru Ivan A. Lisitsa - MD; ivan_lisitsa@mail.ru 